\title{
Deliberation for Consensus in Mediating Industrial Dispute Settlement
}

\author{
Siti Kunarti \\ Universitas Jenderal Soedirman \\ siti_kunarti@yahoo.co.id
}

\author{
Kartono \\ Universitas Jenderal Soedirman \\ kartonogs@y.mail.com
}

\author{
Sri Hartini \\ Universitas Jenderal Soedirman \\ hartini.wy@g.mail.com
}

\begin{abstract}
The significant number of existing cases in Industrial Relations Court proves that Deliberation for consensus is not yet widely employed as a local wisdom of settlement method in the community. So far, settlement has been conducted in the court that is perceived to deliver justice. This research employs judicial normative method with legal approach in order to answer the problem of dispute settlement. On the other hand, mediation as a way of settlement by means of presenting third party as a mediator other than the court refers to Industrial Dispute Settlement Act no. 2 year 2004 and PERMA no. 1 year 2016 about mediation procedure clearly prescribes mediation as a settlement alternative outside the court. The issuance of PERMA no. 1 year 2016 boosts deliberation for consensus in industrial relation mediation with the sincere intention of the disputing parties as the essential factor and active indication of the mediation process. The result of mediation can be a further reference of consideration for the Industrial Relation Court.
\end{abstract}

Keywords: Mediation, dispute settlement, industrial relations

\section{INTRODUCTION}

The continuous development is aimed at the legal conception which is always able to push and redirect the development as the reflection of the modern legal purposes [1].Mochtar Kusumahatmadja proposed two ideas related to the function of the law in the developmental context. Firstly, the law is a tool of social engineering, which is based on the supposition that the orderliness is required in the social development. Secondly, the law as a tool of development is that the law plays the role as the regulator of human activities to move in the direction desired by the renewal or the development itself [2].

The manpower development is under the government responsibility in order to achieve the welfare as mentioned in Article 27 of the Constitution of the Republic of Indonesia of 1945. Law development conducted through legal renewal should keep paying attention to the plurality of the applicable law as well as the impact of globalization [3]. The Supreme Court of the
Republic of Indonesia has been developing the law in resolving civil cases especially regarding to the duty of passing through the mediation process in the court. Basically, the Article 130 of Het Herzeine Indonesish Reglement (HIR), 154 Rechts Reglement Buitengewesten $(R b g)$ has provided a medium to resolve disputes in a peaceful way. This is much more effective and efficient as the resolution is conducted informally. Besides, such method of resolution is independent, cheap, cooperative, as well as both sides have no emotional tendencies. Practically, the Article $130 \mathrm{HIR}, 154 \mathrm{Rbg}$ is applied only to meet the formal requirements [4], in which the judge, in the beginning of the trial, always asks whether or not both sides have reached an agreement. If both sides have not, the trial will go on, which in the end the judge will recommend both sides to have reconciliation. Such way in applying the Article 130 HIR makes the civil cases to stop in the Supreme Court, leading the accumulated cases in the Supreme Court. It is certainly contradictory to the principle of justice, which is simple, fast, and low cost [5].

Industrial Relation Court is a specific court established as the result of the demands toward disputes resolution arising in between employees or labors and the capital holders. The realization of a fast, simple, and low cost trial is the desire of every justice seeker.

Additionally, the quantity of the case received in the District Court is increasing every year. It means that the cases in the High Court, especially in the Supreme Court, are increasing as well. It can be a burden for the Supreme Court as the result of our own judicial system. Meanwhile, the industrial relation conflicts between stakeholder and labors frequently occur as the advancement of the industry itself. Therefore, it will have bad impacts to the economic condition and the harmony of the labors and stakeholders, leading to the difficulty of actualizing the labors' right as well as the disturbance of national stability due to the welfare of the labors receiving less attention.

Mediation as one of dispute settlement methods outside the court emphasizes Deliberation for consensus. Failed mediation becomes a requirement for a call upon trial in Industrial Relations Courts. Now the problem arises on how to determine the principle of Deliberation for consensus in industrial relation dispute settlement. 


\section{METHOD}

This research is a normative legal research, studying the data based on law material on literature which is a process to figure out law regulation, as well as law doctrines in order to answer the following legal issues. In addition, the research uses statute approach and conceptual approach.

\section{RESULT}

\section{Mediation Prescription}

As the highest institution holding judicial power justice, the Supreme Court has the authority to adjudicate the cases filed and asked for judicial review, as well as keeping the implementation of legal order in the four institutions under its authority. One of the functions is to fill legal vacuum in the legislation by making the Supreme Court Regulation (PERMA) which becomes a technical rule in functioning law enforcement fairly. One of the regulations is the PERMA no. 1 of 2016 concerning Mediation which is an improvement to the PERMA no. 1 of 2008.

Mediation is a negotiating process in dispute settlement in which external parties are neutral and not cooperating with one of the disputing parties in order to help them achieve the agreement as the result of a pleasing Deliberation. Unlike the judges and arbiters, mediators have the authority to adjudicate the conflict among parties; even the disputing parties authorize the mediators to help solve the problems [6].

Mediation as stated in Act Number 2 of 2004 is a separate regulation which differs from the mediation stated in PERMA no 1 of 2016 because mediation here means the process before trial or external process. Mediation in industrial relation is an exception from the PERMA no. 1 of 2016 which is regulated in Article 4 section 2 stating that exception case mediated is broader than before, which is civil cases, except cases on Trade Court, Industrial Relation Court, filed an objection toward adjudication of Commission of Business Competition Monitor, Association of Consumer Dispute Settlement, Commission of Information, etc. From the article, it means that industrial relation mediation is a separate mechanism that is not subject to the PERMA no. 1 of 2016 since it has its own exclusivity. Mediation is a good-faith-based ordinance, in which the disputing parties submit suggestions through the way to be solved by the mediators, because the disputing parties are unable to. Through such freedom, it enables the mediators to resolve innovatively through a settlement that cannot be conducted in court. However, the disputing parties still gain benefits. In industrial relation mediation, Deliberation for consensus is the main principle that should be prioritized before the written recommendation from the mediators. Besides, it has the principle of freedom of choosing dispute settlement institution, as well as quick, appropriate, and low cost principles. In relation to those principles, the Act Number 2 Year 2004 places the Industrial Relation Court as a secondary option or ultimum remedium in dispute settlement, right after mediation and conciliation.

The desire of the legislator of the Act no. 2 of 2004 by the existence of Industrial Relation Court as an exclusive court and the principle of Deliberation for consensus is that the realization of the relationship problems between workers and employers is not just an ordinary civil case. Both parties have different standing, and dispute settlement through reconciliation is much more effective and efficient. Therefore, it is so reasonable for the development of various settlement methods out of the court, which is also known as Alternative Dispute Resolution (ADR), such as mediation, conciliation, expert determination, and mini trial [7].

The neutrality of the mediator should look at the existing problem, the mediator may give a view to the parties when they notice an imbalanced or unfair process, it is necessarily applied to keep what is produced through mediation does not result in a violation of law (legal defect) or violate the custom (ethics / customs) that exists in society. The existence of the neutrality of the mediator is in a position where the parties are still mutually beneficial, so that no party feels harmed in the agreement. The mediator is in the "middle and neutral" position between the disputing parties, and seeks to find a number of agreements so as to achieve satisfactory results of the parties to the dispute [8].

\section{Deliberation for Consensus in the Industrial Dispute Settlement Mediation}

The discussion on the scope of deliberation in resolving the issues of social life, nation, and state shows that deliberation is an absolute necessity to be enforced, both on life problems that have no clear definitions (Qur'anic verses and Hadiths) as well as procedures for the implementation of the problem of the existing definitions, such as the consultative institutions, the implementation of the livelihood of the civil or the people, the mandate that will be given to the leaders, the appointment of leaders, the system of living the nation and the state, education or cultural affairs, politics, economy, law, and environment. Associated with religious affairs that already exist, the definition (Nash) needs to be discussed about the practice or law enforcement in life. In essence, consensus deliberation has become the local wisdom that grows in the life of Indonesian society. This continues to be developed in the process of democracy from the simplest and the lowest to the highest level in the administration of the state.

Labor law in the case of industrial relations is one of the responsibilities of the government in the development of the field of employment. Therefore, in the situation of a dispute, then the regulation of industrial relations regulates 
how to resolve the dispute by way of deliberation as the noble value of the Indonesian nation that has become a local wisdom that must be upheld. The mechanism of settlement of industrial relations in consensus agreement as local wisdom is clearly regulated in Article 3 of Law no. 2 Year 2004 on Industrial Relations Disputes Settlement stating that Industrial relations disputes must be strived to resolve first in advance through bipartite Deliberations by deliberation to reach the consensus.

The settlement of industrial relations disputes through mediation is conducted under several provisions, such as:

1. Conducted by a mediator located in each office of the agency responsible for the labor department of the district and city;

2. Settlement of disputes through mediation shall be made within 30 days in accordance with Article 10 UUPPHI;

The mediator arranges meetings for both parties to notice the core of the case and give each other an argument and if an agreement is reached between the parties, the parties sign the Collective Agreement witnessed by the mediator, and it is registered in the Industrial Relations Court at the District Court in the jurisdiction of the parties to obtain the certificate of registration;

1. If the agreement is not reached, then dispute settlement proceeds to appeal through the Industrial Relations Court at the local District Court. In this case, disputes must be resolved within 30 (thirty) days;

2. If the Mediation Deliberation does not reach an agreement, then:

a. Mediator issued written advice;

b. Written advice no later than 10 working days from the first mediation session must be submitted to the parties;

c. The parties shall provide written replies to the mediator whose contents receive or reject the written advice within no later than 10 working days after receiving written advice;

d. Parties who do not give their opinion are considered to reject written advice. If an agreement is reached then mediation within 3 days helps to create a Joint Agreement to be registered with the IRC in the local $\mathrm{PN}$. Conversely, if no agreement is reached, the parties may choose to settle the dispute through Conciliation or Arbitration according to the type of dispute. Even dispute resolution opportunities through the IRC can be made, as dispute resolution through the IRC must be a treatise stating a failed Mediation or Conciliation settlement.

The emphasis of Deliberation for consensus can be identified from the process of mediation in which disputing parties are invited to deliver their views and discuss the subject matter. Reviewing the process of industrial relations dispute settlement is basically very clear that Law no. 2 Year 2004 on industrial relations dispute settlement priors the Deliberation consensus as local wisdom starting from Biparti settlement. That is settlement of both parties between workers with entrepreneurs as an obligation which must be done before settlement of dispute on other settlement mechanisms.

\section{CONCLUSION}

Deliberation for consensus as the noble values of the nation's personality listed in Pancasila has become the basis for the settlement of industrial relations disputes. This is clearly regulated in Article 3 of Law no. 2 Year 2004 on the Settlement of Industrial Relations Preservation also in Perma No. 1 of 2016 on Mediation that excludes Industrial Relations Court cases from independent mediation.

The issuance of PERMA no. 1 year 2016 boosts Deliberation for consensus in industrial relation mediation with the sincere intention of the disputing parties as the essential factor and active indication of the mediation process. The result of mediation can be a further reference of consideration for the Industrial Relation Court.

Therefore, an effective dispute resolution model by maximizing consensus deliberation as a local wisdom in mediation settlement becomes very important and plays a role as a guide for the sake of harmonious industrial relations.

\section{REFERENCES}

[1] Aam Suryamah"Aspek Hukum Acara Perdata dalam Penyelesaian Perselisihan Hubungan Industrial, Jurnal Hukum Acara Perdata ADHAPER, Vol. 2, No. 1, January - June 2016 [77-93]

[2] Mochtar Kusumaatmadja. Pengantar Ilmu Hukum, Alumni, Bandung. p 4. 2009.

[3] HibnuNugroho, 'Paradigma Penegakan Hukum Indonesia Dalam Era Global'26, Jurnal Pro Justitia [320-321]. 2006.

[4] Riri Nazriyah,'Peranan Cita Hukum Dalam Pembentukan Hukum Nasional'. Jurnal Hukum Ius Quia Iustum, 9 [2]: $136-151.2002$

[5] Fence M Wantu, 'Mewujudkan Kepastian Hukum, Keadilan Dan Kemanfaatan Dalam Putusan Hakim Di Peradilan Perdata', Jurnal Dinamika Hukum., 12 [3]: 479-489.

[6] Triana Sofiani, 'Efektivitas Mediasi Perkara Perceraian Pasca Perma Nomor 1 Tahun 2008 Di Pengadilan Agama' (2010) Jurnal Penelitian.; 7 (2)

[7] Rahadi Wasi Bintoro, Kajian Ontologis Lembaga Mediasi Di Pengadilan, Jurnal Penelitian Yuridika: Volume 31 [1]: 121-142 
[8] Mardalena Hanifan, Kajian Yuridis: Mediasi sebagai alternative Penyelesaian Sengketa Perdata Di Pengadilan, Jurnal Hukum Acara Perdata ADHAPER, Vol. 2, No. 1, January - June 2016, [113] 
